\title{
Efficacy of an intrathecal multidrug infusion for pain control in older adults and in end-stage malignancies: A report of three cases
}

\author{
Sadegh Abdolmohammadi MD¹, Pierre-Olivier Hétu PhD CSPQ FCACB ${ }^{2}$, \\ Andrée Néron BPharm $\mathrm{DPH}^{3}$, Gilbert Blaise $\mathrm{MD}^{4}$
}

\begin{abstract}
S Abdolmohammadi, PO Hétu, A Néron, G Blaise. Efficacy of an intrathecal multidrug infusion for pain control in older adults and in end-stage malignancies: A report of three cases. Pain Res Manag 2015;20(3):118-122.

The aim of the present study was to explore the effectiveness of an alternative method to manage pain based on a time-limited intrathecal (IT) infusion of an analgesic medication mixture. Three patients $(69,64$ and 94 years of age) with intractable and poorly controlled pain due to bed sores, pelvic metastatic mass, and thoracic vertebra and rib fractures, respectively, were treated. Daily doses of opioids could not be increased due to side effects. An IT catheter $(20 \mathrm{G})$ was placed by percutaneous approach in the lumbar area while advancing toward the thoracic region, and was then tunnelled and fixed subcutaneously. It was connected to an external infusion pump with a mixture of bupivacaine $1 \mathrm{mg} / \mathrm{mL}$, naloxone $0.02 \mathrm{ng} / \mathrm{mL}$, ketamine $100 \mu \mathrm{g} / \mathrm{mL}$, morphine $0.01 \mathrm{mg} / \mathrm{mL}$ and clonidine $0.75 \mu \mathrm{g} / \mathrm{mL}$. The starting rate was $1 \mathrm{~mL} / \mathrm{h}$. The pain was mostly controlled at a rate of $<1 \mathrm{~mL} / \mathrm{h}$. Opioid consumption was reduced dramatically. The catheter was kept in place for one month in the first and third patients, and for six months in the second patient, until his death. Major side effects, such as hypotension, constipation, muscle weakness, sphincter dysfunction, and cognitive or mood deterioration, were not observed with this approach. One patient experienced a urinary tract infection followed by sepsis and meningitis, which was cured by antibiotics. The catheter was removed in this patient. IT infusion with a low-concentration multidrug mixture could be considered as an alternative modality for intractable pain relief in older adults or in malignancies.
\end{abstract}

Key Words: Clonidine; Intrathecal; Ketamine; Malignancy; Naloxone; Older adults

$\Delta$ chieving effective, durable and safe pain relief, especially in - 1 elderly patients and those with end-stage malignancies, can be a clinical challenge (1-6). Despite multimodal systemic approaches with the lowest possible doses of drugs to decrease systemic side effects, pain in these patients is often poorly controlled, with unacceptable side effects in some patients. We present a case series of three patients whose pain was treated using a time-limited intrathecal (IT) infusion of a multidrug analgesic mixture.

\section{CASE PRESENTATIONS}

Three patients who were admitted in hospital were treated with IT infusion (Table 1). The numerical rating scale (NRS-11) was used to measure pain intensity in the patients.

Case 1

A 69-year-old woman with a history of laryngectomy due to laryngeal neoplasia, diabetes and stroke (with hemiparesis) was admitted to hospital for dysphagia and a large painful sacral bed sore. Dysphagia

\section{L'efficacité d'une polythérapie par perfusion intrathécale pour contrôler la douleur chez des adultes âgés atteints d'un cancer en phase terminale : un rapport de trois cas}

Le présent rapport visait à explorer l'efficacité d'une méthode différente pour gérer la douleur fondée sur une perfusion intrathécale et limitée dans le temps d'un mélange d'analgésiques. Trois patients (de 69, 64 et 94 ans) souffrant d'une douleur réfractaire et mal contrôlée en raison de plaies de lit, d'une masse métastatique pelvienne et de fractures des vertèbres thoraciques et des côtes, ont été traités. Il était impossible d'accroître les doses quotidiennes d'opiö́des en raison des effets secondaires. Un cathéter intrathécal (calibre 20) a été installé par abord percutané dans la région lombaire, orienté vers la région thoracique, puis tunnelisé et fixé par voie sous-cutanée. Il a été relié à une pompe de perfusion externe contenant un mélange de $1 \mathrm{mg} / \mathrm{mL}$ de bupivacaïne, de $0,02 \mathrm{ng} / \mathrm{mL}$ de naloxone, de $100 \mu \mathrm{g} / \mathrm{mL}$ de kétamine, de $0,01 \mathrm{mg} / \mathrm{mL}$ de morphine et de $0,75 \mu \mathrm{g} / \mathrm{mL}$ de clonidine. La dose de départ était de $1 \mathrm{~mL} / \mathrm{h}$. La plupart du temps, la douleur était contrôlée par une dose de moins de $1 \mathrm{~mL} / \mathrm{h}$. La consommation d'opioïdes a considérablement diminué. Le cathéter a été maintenu en place un mois chez le premier et le troisième patients, et six mois chez le deuxième patient, jusqu'à son décès. Cette méthode n'a causé aucun effet secondaire important, tel que l'hypotension, la constipation, la faiblesse musculaire, la dysfonction du sphincter et la détérioration observée de la cognition ou des humeurs. Un patient a souffert d'une infection urinaire suivie d'une sepsie et d'une méningite, traitée aux antibiotiques. La perfusion intrathécale d'une polythérapie à faible concentration peut être envisagée pour soulager une douleur réfractaire chez des adultes plus âgés ou cancéreux.

was due to esophageal stricture, which was properly managed by dilation using an endoscopic procedure. The pain was difficult to control using conventional pain treatment. At the time of admission, she was using gabapentin $2400 \mathrm{mg} /$ day, acetaminophen $3 \mathrm{~g} /$ day to $4 \mathrm{~g} /$ day and fentanyl patch $25 \mu \mathrm{g} / \mathrm{h}$ every three days. The fentanyl patch was increased to $50 \mu \mathrm{g} / \mathrm{h}$ and parenteral morphine was prescribed as a breakthrough dose. A total oral-equivalent morphine daily dose of $220 \mathrm{mg}$ was unsuccessful in controlling the pain. Due to side effects, it was not possible to increase the opioid dose.

Case 2

A 64-year-old man with a history of end-stage rectal adenocarcinoma with liver and pelvic metastasis along with sacral plexus involvement due to a pelvic metastatic mass $(10 \mathrm{~cm} \times 14 \mathrm{~cm} \times 7 \mathrm{~cm}$ in size $)$ was experiencing excruciating pelvic and sacral pain that was refractory to the typical pharmacological approach (oral or parenteral opioids). The patient's medical history included partial hepatectomy, proctectomy, radiotherapy and chemotherapy. Magnetic resonance imaging indicated

${ }^{1}$ Department of Anesthesiology and Pain Clinic; ${ }^{2}$ Department of Biochemistry; ${ }^{3}$ Department of Pharmacy; ${ }^{4}$ Department of Anesthesiology and

Medicine, Pain Clinic, Centre hospitalier de l'Université de Montréal (CHUM), University of Montreal, Montreal, Quebec

Correspondence: Dr Sadegh Abdolmohammadi, Notre-Dame Hospital, 1560 Sherbrooke Street East, Pavillon Deschamps, local FS-1136,

Montreal, Quebec H2L 4M1. Telephone 514-890-8202, fax 514-412-7520, e-mail samohammadi@yahoo.com 
TABLE 1

Comparison of opioid consumption before and after intrathecal (IT) catheter insertion

\begin{tabular}{|c|c|c|c|c|c|c|}
\hline Patient & Age, years & Sex & Cause of pain & $\begin{array}{c}\text { Equivalent oral morphine } \\
\text { before IT, mg/day* }\end{array}$ & $\begin{array}{l}\text { Equivalent oral morphine } \\
\text { after IT, mg/day* }\end{array}$ & $\begin{array}{l}\text { Maximal inpatient IT } \\
\text { infusion rate, } \mathrm{mL} / \mathrm{h}\end{array}$ \\
\hline 1 & 69 & Female & Bed sore & 220 & 30 & 1 \\
\hline 2 & 64 & Male & Pelvic metastatic cancer & $\begin{array}{c}375+\text { methadone } \\
24 \mathrm{mg} / \text { day }\end{array}$ & 60 & $2.5^{\dagger}$ \\
\hline 3 & 94 & Female & $\begin{array}{c}\text { Rib and thoracic vertebra } \\
\text { fracture }\end{array}$ & 200 & 30 & 1 \\
\hline
\end{tabular}

${ }^{*}$ Calculated on the basis of opioid equianalgesic dose conversion table (Montreal University Hospital [CHUM], Montreal, Quebec), ${ }^{\dagger}$ In this patient, the concentration of drugs was modified to avoid passing the maximum intrathecal daily dose of bupivacaine (see text).

a large pelvic mass with invasion of the left L4-L5, L5-S1 and sacral foramina, possibly explaining the intractable pelvic and left leg pain. Because of the advanced stage of this malignancy, the patient was not a candidate for a surgical approach; thus, the palliative care team started to manage the patient. Treatment with $30 \mathrm{mg} /$ day parenteral hydromorphone plus $24 \mathrm{mg} /$ day oral methadone (resulting in adverse reactions such as hallucination and drug interaction) and oral dexamethasone up to $16 \mathrm{mg} /$ day did not successfully control patient's pain.

\section{Case 3}

A 94-year-old woman with multiple thoracic vertebra and ribs fractures (based on imaging analysis, a confirmed fracture on T9 without neurological compromise, left third to sixth rib fractures and suspected fractures on T7, T8, T10 and T11) due to a fall reported intractable pain, making the patient bedridden. She had type 2 diabetes mellitus (wellcontrolled by metformin) and good cardiac and renal function (ejection fraction $60 \%$, urea level $6.9 \mathrm{mmol} / \mathrm{L}$, creatinine level $48 \mu \mathrm{mol} / \mathrm{L}$ and glomerular filtration rate $89 \mathrm{~mL} / \mathrm{min} / 1.73 \mathrm{~m}^{2}$ ). The pain was difficult to control by conventional pain treatment. An attempt was made to control the pain by prescribing hydromorphone up to $10 \mathrm{mg}$ to $15 \mathrm{mg}$ orally or parenterally per day, acetaminophen $4 \mathrm{~g} /$ day and fentanyl patch up to $50 \mu \mathrm{g} / \mathrm{h}$ every three days. A 10 day course of treatment with celecoxib $200 \mathrm{mg} /$ day did not successfully decrease the pain. Despite high doses of opioids, the pain was not successfully controlled, and the patient experienced side effects. As well, despite this treatment, severe pain rendered the patient completely bedridden.

Due to the inability to control the pain and remarkable side effects, after discussion with the patients and the attending physicians, an IT approach for pain management was attempted. Informed consent was obtained from each patient. In all three patients, an IT catheter 20G was placed using a percutaneous approach in the lumbar area (L2-L3 or L3-L4) advancing to thoracic region, then tunneled and fixed subcutaneously. It was connected to an external infusion pump with a mixture of bupivacaine $1 \mathrm{mg} / \mathrm{mL}$, naloxone $0.02 \mathrm{ng} / \mathrm{mL}$, ketamine $100 \mu \mathrm{g} / \mathrm{mL}$, morphine $0.01 \mathrm{mg} / \mathrm{mL}$ and clonidine $0.75 \mu \mathrm{g} / \mathrm{mL}$. All of these medications were preservative-free, except for naloxone, which was not available preservative-free at that time. The starting rate of infusion was $1 \mathrm{~mL} / \mathrm{h}$. In all three patients, pain was successfully controlled, and oral or parenteral opioid requirements decreased significantly. Acetaminophen was continued at $3 \mathrm{~g} /$ day to $4 \mathrm{~g} / \mathrm{day}$ in all cases. The infusion rate was adjusted during the following days according to patients' requirement for pain relief (based on the NRS-11 in rest time and normal daily activities).

\section{RESULTS}

In the first patient, following the catheter insertion and an infusion rate of $1 \mathrm{~mL} / \mathrm{h}$, pain decreased dramatically as parenteral morphine was stopped, and the fentanyl patch and gabapentin were decreased to $12 \mu \mathrm{g} / \mathrm{h}$ and $1200 \mathrm{mg} /$ day, respectively. Parenteral hydromorphone was considered as breakthrough treatment during bed sore dressing. The patient's analgesic requirements remained stable at an infusion rate of $\leq 1 \mathrm{~mL} / \mathrm{h}$. The infusion bag was changed every $24 \mathrm{~h}$. Meanwhile, the bed sore healed almost completely. After one month of this treatment, following an episode of fever, a sepsis workup was performed that revealed a urinary and cerebrospinal fluid (CSF) reaction. Despite immediate parenteral antibiotics, the fever continued; therefore, the catheter was removed. Klebsiella pneumoniae was detected in the urine and CSF culture. Surprisingly, despite catheter removal, the patient did not request an increase in pain medication. She left hospital in good condition without any sequelae.

In the second patient, pain was not successfully controlled by oral dexamethasone $16 \mathrm{mg} /$ day, parenteral hydromorphone $30 \mathrm{mg} /$ day, oral methadone $24 \mathrm{mg} /$ day and acetaminophen $3 \mathrm{~g} /$ day. Due to opioid and coanalgesic side effects (such as delirium), it was not possible to either increase dosage or to add any other agent. The patient had a history of allergy to morphine; for this reason, the mixture was prepared with an equivalent dose of preservative-free hydromorphone (a hydromorphonemorphine ratio of 1:5). Following catheter insertion, the pain dramatically decreased with an infusion rate of $1 \mathrm{~mL} / \mathrm{h}$. Hydromorphone was used for breakthrough pain control. Based on the needs of the patient, the infusion rate was increased to $2.5 \mathrm{~mL} / \mathrm{h}$, but to avoid passing the limit of the intrathecal bupivacaine daily dose, the mixture was altered, as follows: hydromorphone $3 \mu \mathrm{g} / \mathrm{mL}$, clonidine $1.25 \mu \mathrm{g} / \mathrm{mL}$, naloxone $0.02 \mathrm{ng} / \mathrm{mL}$, ketamine $100 \mu \mathrm{g} / \mathrm{mL}$ and bupivacaine $0.7 \mathrm{mg} / \mathrm{mL}$. The infusion bag was changed every $24 \mathrm{~h}$. At this point, the patient occasionally requested hydromorphone. Methadone was decreased and stopped during the following days. Dexamethasone was gradually decreased to $0.75 \mathrm{mg} /$ day. The infusion rate was gradually decreased to $1 \mathrm{~mL} / \mathrm{h}$ and the patient left the hospital in good condition. For sterility reasons, the drugs' concentration was increased during the outpatient period. This allowed a decrease in the infusion rate (with the same daily dose) and the bag was changed every $72 \mathrm{~h}$. The catheter was kept in place up to five months out of the hospital under the supervision of a family physician. The patient subsequently died of his cancer. During the final days of his life, the infusion rate was increased to control his pain and make him comfortable during the terminal phase.

In the third patient, the pain decreased dramatically with the treatment; as a result, hydromorphone was no longer required (it was prescribed for use as needed, but the patient never requested it). As a supplement, $12 \mu \mathrm{g} / \mathrm{h}$ fentanyl patch every three days and topical lidocaine were used. The infusion rate was gradually decreased to $0.3 \mathrm{~mL} / \mathrm{h}$ based on patient pain relief and satisfaction (based on the NRS-11) in rest time and normal daily activities and finally stopped after one month. The catheter was then removed. There was a local irritation at the catheter exit point without any systemic manifestation, which was successfully controlled by local care. The patient left the hospital in good condition.

There were no remarkable side effects, such as catheter insertion site infection, constipation, muscle weakness, sphincter dysfunction, cognitive or mood deterioration, in our patients. Chemical stability testing of the drug mixture was assessed by the biochemistry department during a five-day period at room temperature in the dark. Drug mixtures were made from the same reagents used for administration to the patients. Solutions were prepared in $0.9 \% \mathrm{NaCl}$ in $50 \mathrm{~mL}$ clear plastic bags and contained $1 \mathrm{mg} / \mathrm{mL}$ bupivacaine, $0.02 \mathrm{ng} / \mathrm{mL}$ naloxone, $100 \mu \mathrm{g} / \mathrm{mL}$ ketamine, $0.01 \mathrm{mg} / \mathrm{mL}$ morphine, and $0.75 \mu \mathrm{g} / \mathrm{mL}$ clonidine. The appearance of the solution was monitored by visual inspection, and the drug concentrations were quantified by liquid chromatography coupled to tandem mass spectrometry. No change in appearance was observed during the five-day period. The ketamine 


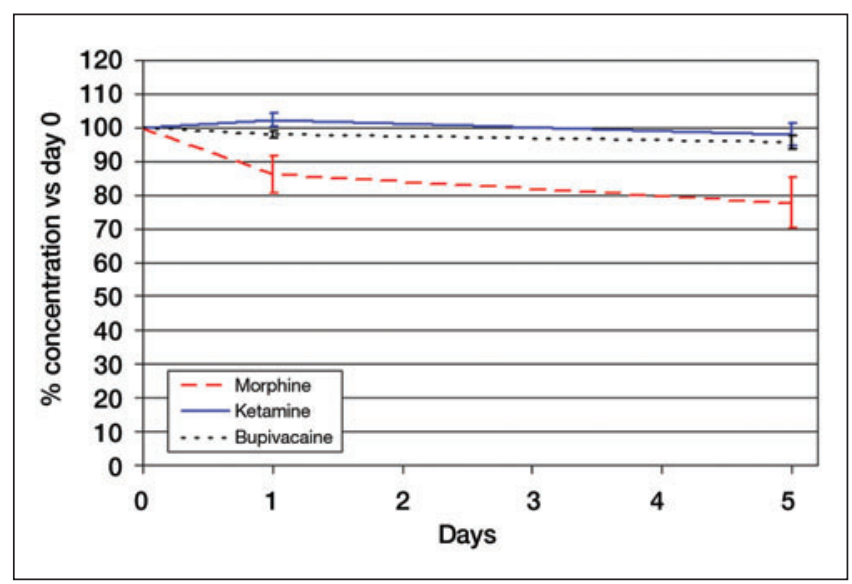

Figure 1) Stability of the drugs in the prepared solution at room temperature during five days measured by tandem mass spectrometry. Solution contains bupivacaine $1 \mathrm{mg} / \mathrm{mL}$, naloxone $0.02 \mathrm{ng} / \mathrm{mL}$, ketamine $100 \mu \mathrm{g} / \mathrm{mL}$, morphine $0.01 \mathrm{mg} / \mathrm{mL}$ and clonidine $0.75 \mu \mathrm{g} / \mathrm{mL}$ in $\mathrm{NaCl} 0.9 \%$ in a $50 \mathrm{~mL}$ clear plastic bag. The solution was kept in the dark for the duration of the experiment. The concentration of ketamine and bupivacaine was stable but the concentration of morphine decreased $15 \%$ on the first day and then stayed mostly unchanged during the following days. It was not possible to effectively assess the stability of naloxone or clonidine at these low concentrations

and bupivacaine concentrations did not change over time. Morphine concentration decreased by approximately $15 \%$ on the first day and remained relatively steady during the following days (Figure 1). Naloxone and clonidine levels were not effectively detected at these low concentrations.

\section{DISCUSSION}

Pain management is a considerable challenge in older adults and those with end-stage malignancies. Age-related comorbidities, polymedication and physiological changes in this age group limit liberal use of systemic opioids and NSAIDs (7). In neuroaxial analgesia, IT has less undesirable drug-related side effects due to fewer doses. Moreover, the evidence shows better results for an IT approach when compared with an epidural approach for cancerrelated pain $(2 \mathrm{~B}+$ and $2 \mathrm{C}+$ respectively) (8). Morphine, baclofen and ziconotide are the only Food and Drug Administration-approved medications for IT use. Apart from bupivacaine, the other drugs have been used successfully via IT approach at higher doses than those used for our patients (Table 2).

In our drug mixture, we used morphine, hydromorphone, bupivacaine and clonidine. These are drugs that have been already used successfully by the IT method (9). In chronic pain syndromes, morphine is the opioid of first choice for IT administration. Morphine has hydrophilic properties and, thus, will spread more than fentanyl (and sufentanil) after IT administration, extending the area of analgesia. Its presynaptic and postsynaptic effects are via G-protein-linked opioid mu (mainly), delta and kappa receptors. Presynaptic interaction inhibits the release of substance $\mathrm{P}$ and calcitonin gene-related peptide by means of interactions with $\mathrm{N}$-type voltage-dependent calcium channels and reduced calcium influx. Postsynaptic activation of opioid receptors leads to inhibition of adenylate cyclase and also results in the opening of potassium channels, which, in turn, causes hyperpolarization, rendering the postsynaptic second-order neuron less responsive (10).

The effect of local anesthetics is via blocking the $\mathrm{Na}^{+}$channels of neuronal tissue and disrupting pain transmission. In the clinical setting, the IT bupivacaine dose ranges from $3 \mathrm{mg} /$ day to $50 \mathrm{mg} /$ day (9). The recommended dose of bupivacaine combined with opioids is between $1 \mathrm{mg} /$ day and $14 \mathrm{mg} /$ day, and doses up to $>30 \mathrm{mg} /$ day did not cause bladder dysfunction or muscle weakness (10). On the other hand, a dose of up to $100 \mathrm{mg} /$ day has been reported (11). In our cases, two patients usually received a $\leq 1 \mathrm{~mL} / \mathrm{h}$ infusion rate, which was
TABLE 2

Comparison of recommended intrathecal daily drug doses and doses used in the present study

\begin{tabular}{lcc}
\hline Drug & Recommended dose (9) & Dose used in the present study* \\
\hline Morphine & $1-20 \mathrm{mg}$ & $0.08-0.24 \mathrm{mg}$ \\
Bupivacaine & $4-30 \mathrm{mg}$ & $8-24 \mathrm{mg}$ \\
Clonidine & $30-1000 \mu \mathrm{g}$ & $6-18 \mu \mathrm{g}$ \\
Naloxone & no data available & $0.2-0.5 \mathrm{ng}$ \\
Ketamine & $1-50 \mathrm{mg}$ & $1-2.4 \mathrm{mg}$ \\
\hline
\end{tabular}

${ }^{*}$ Calculated on the basis of $\leq 1 \mathrm{ml} / \mathrm{h}$ infusion rate

equivalent to $\leq 24 \mathrm{mg} /$ day. The maximum inpatient dose of bupivacaine for the second patient was $42 \mathrm{mg} /$ day.

Clonidine is an alpha2-receptor agonist, which is located in both presynaptic and postsynaptic neurons. Interaction with this receptor results in reduced presynaptic calcium entry and an increased potassium influx postsynaptically, which initiates hyperpolarization of the postsynaptic cell membrane (10). Combined with local anesthetics and morphine, clonidine is reported to have a synergistic action for pain relief (9). An IT administration of clonidine (average daily dose ranges from $50 \mu \mathrm{g}$ to $200 \mu \mathrm{g}$ ) reduces the risk of morphine tolerance and, thus, lessens the risk for opioid-related adverse effects due to dose escalation (10). Side effects include dry mouth, sedation, bradycardia and hypotension. Sudden discontinuation of long-term IT therapy may lead to rebound hypertension, panic attacks and psychotic behaviour (12).

Naloxone is an opioid mu-receptor competitive antagonist, but in low dose (in fact 'ultra-low dose'), it helps in controlling pain and prevents hyperalgesia (13). A review of the literature suggests that under certain conditions, low-dose opioid antagonists (alone or in combination with opioids) can produce an antinociceptive or analgesic response (14). Furthermore, they have been used successfully in Crohn disease and irritable bowel syndrome to control diseaseassociated pain. The possible mechanisms of action may be upregulation of opioid receptors, increased levels of endogenous opioids, decreased opioid receptor coupling to stimulatory G-proteins (mediated through filamin A) and an inhibition of opioid agonist-induced activation of glial cells (14). In a recent study by Mattioli et al (15), it was demonstrated that coadministration of morphine with ultra-lowdose naltrexone attenuates gliosis in rats, which was noted by an attenuation of the increase of the glial proteins GFAP and CD3/ $\mathrm{CD} 11 \mathrm{~B}$, increase in astrocyte cell volume and astrocyte proliferation. Their IT use alone or in combination with opioids could have an analgesic effect, as shown in animal models (16). In an animal model study, ultra-low dose naloxone enhanced the antihyperalgesia and antiallodynia effects of morphine in rats, possibly by reducing tumour necrosis factor-alpha and tumour necrosis factor receptor-1 expression and excitatory amino acids (EAAs) such as glutamate and aspartate concentrations in the spinal dorsal horn (17). In a case report, adding $50 \mathrm{ng} /$ day naloxone to the IT morphine infusion dramatically enhanced the analgesic effect of morphine without apparent side effects for more than three years (18). These mechanisms can partially explain the analgesic role of the naloxone in our mixture. The mechanistic rationale for naloxone/morphine dose and concentration ratio was based on animal studies and a case report (18) in which an IT naloxone:morphine concentration ratio of $1: 100,000$ was efficient in controlling pain for three years. One potential concern is the remote possibility of naloxone neurotoxicity. It is not approved for IT use, but its extremely low concentration, molecular characteristics and animal studies could make it safe for IT use. The molecular structure of naloxone is virtually identical to morphine except in a minor moiety substitution at position 9 (or 13). Furthermore, IT naloxone plus morphine in rodents has not demonstrated signs of spinal cord toxicity $(16,19)$. As well, some studies show naloxone provides neural protection against ischemic situations (20). Due to chemical characteristics, ultra-low concentration and animal studies, it appears to be unlikely that IT naloxone would produce spinal 
cord toxicity. At the time of our (current) study, naloxone was not available as a formulation without preservative.

Ketamine is an intravenous anesthetic which has analgesic effect in subanesthetic doses. It has an antihyperalgesic effect due to its impact on $N$-methyl-D-aspartate (NMDA) receptors (21) and an antiallodynic effect by suppressing toll-like receptor (TLR)-mediated signal transduction (22). It could be used as IT approach in end-stage cancer related pain (23). Ketamine possesses a plethora of other actions that enhance its analgesic properties. These include blocking non-NMDA glutamate and muscarinic cholinergic receptors, facilitating GABA-A signalling, weakly binding to opioid receptors, and possessing local anesthetics as well as possibly neuroregenerative properties (9). Ketamine shows anti-inflammatory (24), antidepressant (25) and procognitive (26) effects, and a beneficial effect on respiration, which can counter the side effects of morphine. In one recent study, an epidural infusion of subanesthetic doses of $S(+)$-ketamine during thoracic surgery provides better postoperative analgesia than epidural ropivacaine (27). Ketamine has been used successfully to control cancer and noncancer pain. The main concern is a possible neurotoxic effect during long-term IT use (even with preservative-free $S(+)$-enantiomer). In one recent animal study, IT injection of a large dose of $1 \mathrm{mg} / \mathrm{kg}$ in dogs had no histological alterations of spinal tissue or meninges (28). As well, there is more evidence showing that IT infusion of ketamine would be useful in end-stage cancer related pain (23). Despite some studies reporting neurotoxicity following IT ketamine $(29,30)$, Malinovsky et al (31) showed in an animal model that neurotoxicity of ketamine could be due to the preservatives. The dose used in our study is much less than the one in these reports, and as mentioned previously, the other studies do not show neurotoxic effects in animal models (28). On the other hand, the beneficial effects of ketamine in the inflammatory process and postoperative outcome should not be neglected. In a recent article, De Kock et al (32) reviewed the effect of ketamine on the inflammatory process. They concluded that ketamine is an immunomodulator, which prevents the exacerbation and the extension of local inflammation without blunting the local process and delaying inflammatory resolution. This can explain some beneficial aspects of this drug in postoperative outcomes and cognitive dysfunction. Moreover, repeated high doses of ketamine may exhibit neurotoxic effects in immature brains in the absence of noxious stimuli, whereas it may be neuroprotective in the same brains in the presence of strong painful stimuli (33). Controversy continues about IT ketamine, but using low-dose preservative-free ketamine in older adults and patients with end-stage malignancies with intractable pain would be a reasonable choice in pain management.

Comparison of systemic opioid consumption (oral and parenteral) before and after catheter insertion showed a significant reduction in daily dose of opioids in our patients (Table 1). The equivalent dose of IT morphine could not explain this reduction. Although there is no consensus regarding the IT to oral opioid conversion rate (34), using maximum conversion ratio calculated by Krames (35) shows that our doses after catheter insertion are considerably less than the doses used before insertion. Direct IT infusion, synergistic effect and different mechanisms of action could explain the analgesic effect of our drug combination even at lower concentrations. Due to very low concentration of the drugs (especially ultra-low dose for naloxone), absorption and systemic effects could not be an important factor in the analgesic effect of the mixture.

The consensus guidelines published by Deer et al (36) outline a polyanalgesic algorithm for the use of IT agents. This guideline is for patients for whom the practitioners consider permanent IT pump to be a reasonable alternative for pain management. Although our patients were not in this category, this guideline could still provide some important key points. A combination of morphine-bupivacaine and morphine-clonidine could respectively be a first- and second-line treatment for neuropathic pain. For chronic nociceptive pain, a combination of morphine-bupivacaine and opioid-clonidine are, respectively, second- and third-line treatments.
To achieve sufficient pain relief in the second case, larger doses were required during the short period of admission in hospital and during the final days of the patient's life. Severe metabolic changes due to malignancy, progressive tumour invasion, possible tolerance and local aggravated inflammatory processes that interact with the effects of the prescribed medications may explain a part of this phenomenon.

Physicochemical stability of a drug admixture is assumed if the physical appearance of a solution does not change and drug concentration remains stable. Stability is assumed for an ingredient if the loss is $<10 \%$ of the initial concentration after a period of $96 \mathrm{~h}$. The standards for stability testing were prepared using the same reagents as those administered to the patients. All compounds were included in the stability-testing experiments, including clonidine and naloxone. These experiments were performed in clear plastic bags that were stored in the dark for the duration of the testing. Our stability assessment showed that bupivacaine and ketamine are sufficiently stable over five days at room temperature (Figure 1). There was a $15 \%$ to $20 \%$ reduction in morphine concentration, which may be related to its very low concentration or other factors. This value is under the critical value for stability, but did not decrease further. The infusion bag was changed every $24 \mathrm{~h}$ during hospitalization (inpatient) and every $72 \mathrm{~h}$ at home. No loss of clinical efficacy was observed. It was not possible to effectively assess the stability of naloxone or clonidine at these low concentrations using our liquid chromatography-mass spectrometry assay. Meanwhile, their effect on pain reduction is explained by their ultra-low dose concentration. A more precise, accurate and sensitive method for separation and quantification of active ingredients is under development.

Unfortunately, even using the IT method for pain management, there are always drug-related complications such as constipation, muscle weakness, sphincter dysfunction and cognitive or mood deterioration. However, we did not observe these side effects to be major complications, likely due to positive interactions between the drugs, and very low daily doses and concentrations.

Achievement of satisfactory pain control without major complications using an infusion at a rate $<1 \mathrm{~mL} / \mathrm{h}$ in our patients suggests that this method may be used as an alternative in older adults whose pain cannot be well controlled by conventional opioids. To determine the type and the dose of probable drugs in mixture, more detailed studies involving more patients are required. The main beneficial effect of a drug admixture infusion is the avoidance of multiple injections. It decreases the risk related to line manipulation, confusion with route of administration, simplifies the drug regimen and, in some circumstances, allows the patient to be discharged from hospital to homecare. The other advantage of our tested mixture in a low concentration and lower daily doses is a lower risk of neurotoxicity. However, of greater importance is the pain control in older adults and patients with end-stage cancer. Studies involving a greater number of patients and randomized trials may lead to the discovery of more appropriate drug combinations.

\section{CONCLUSION}

Short-term IT infusion could be considered to be an alternative method in advanced-age and end-stage malignancy pain management. The advantages of this method are better pain control and less systemic side effects because of lower prescribed doses. Further studies are required to determine the type of mixture and related doses for the optimal pain-control conditions with the fewest side effects.

ACKNOWLEDGMENT: The authors thank Muhammad Zafarullah for improving the use of English in the manuscript.

DISCLOSURES: Each author certifies that he or she, or a member of his or her immediate family has no commercial association (ie,consultancies, stock ownership, equity interest, patent/licensing arrangements, etc) that may pose a conflict of interest in connection with the published article. 


\section{REFERENCES}

1. Institute of Medicine. Relieving pain in America: A blueprint for transforming prevention, care, education, and research. <www.iom. edu/ /media/Files/Report\%20Files/2011/Relieving-Pain-in-AmericaA-Blueprint-for-Transforming-Prevention-Care-EducationResearch/Pain\%20 Research\%202011\%20Report \%20Brief.pdf> (Accessed June 13, 2013).

2. Deandrea S, Montanari M, Moja L, Apolone G. Prevalence of undertreatment in cancer pain. A review of published literature. Ann Oncol 2008;19:1985-91.

3. Costantini M, Ripamonti C, Beccaro, et al. Prevalence, distress, management, and relief of pain during the last 3 months of cancer patients' life. Results of an Italian mortality follow-back survey. Ann Oncol 2009;20:729-35.

4. Breivik H, Cherny N, Collett B, et al. Cancer-related pain: A pan-European survey of prevalence, treatment, and patient attitudes. Ann Oncol 2009;20:1420-33.

5. Apolone G, Corli O, Caraceni A, et al. Cancer Pain Outcome Research Study Group (CPOR SG) Investigators. Pattern and quality of care of cancer pain management. Results from the Cancer Pain Outcome Research Study Group. Br J Cancer 2009;100:1566-74.

6. Hong SH, Roh SY, Kim SY, et al. Change in cancer pain management in Korea between 2001 and 2006: Results of two nationwide surveys. J Pain Symptom Manag 2011;41:93-103.

7. Atkinson TJ, Fudin J, Pandula A, Mirza M. Medication pain management in the elderly: Unique and underutilized analgesic treatment options. Clin Ther 2013;35:1669-89.

8. Vissers KC, Besse K, Wagemans M, et al. Pain in patients with cancer. Pain Pract 2011;11:453-75.

9. Cohen SP, Dragovich A. Intrathecal analgesia. Med Clin North Am 2007;91:251-70.

10. Ver Donck A, Vranken JH, Puylaert M, et al. Intrathecal drug administration in chronic pain syndromes. Pain Pract 2014;14:461-76.

11. Van Dongen RT, Crul BJ, De Bock M. Long-term intrathecal infusion of morphine and morphine/bupivacaine mixtures in the treatment of cancer pain: A retrospective analysis of 51 cases. Pain 1993;55:119-23.

12. Ghafoor VL, Epshteyn M, Carlson GH, et al. Intrathecal drug therapy for long-term pain management. Am J Health Syst Pharm 2007;64:2447-61.

13. Aguado D, Abreu M, Benito J, et al. Effects of naloxone on opioid-induced hyperalgesia and tolerance to remifentanil under sevoflurane anesthesia in rats. Anesthesiology 2013;118:1160-9.

14. Taylor R Jr, Pergolizzi JV Jr, Porreca F, Raffa RB. Opioid antagonists for pain. Expert Opin Investig Drugs 2013;22:517-25.

15. Mattioli TA, Milne B, Cahill CM. Ultra-low dose naltrexone attenuates chronic morphine-induced gliosis in rats. Mol Pain 2010;6:22.

16. Lunzer MM, Yekkirala A, Hebbel RP, et al. Naloxone acts as a potent analgesic in transgenic mouse models of sickle cell anemia. Proc Natl Acad Sci USA 2007;104:6061-5.

17. Yang CP, Cherng CH, Wu CT, et al. Ultra-low dose naloxone enhances the antihyperalgesic effects of morphine and attenuates tumor necrosis factor- $\alpha$ and tumor necrosis factor- $\alpha$ receptor 1 expression in the dorsal horn of rats with partial sciatic nerve transection. Anesth Analg 2013;117:1493-502.

18. Hamann S, Sloan PA, Witt W. Low-dose intrathecal naloxone to enhance intrathecal morphine analgesia: A case report. J Opioid Manag 2008;4:251-4.
19. Tsai RY, Jang FL, Tai YH, et al. Ultra-low-dose naloxone restores the antinociceptive effect of morphine and suppresses spinal neuroinflammation in PTX-treated rats. Neuropsychopharmacology 2008;33:2772-82.

20. Hsu YY, Jong YJ, Lin YT, et al. Nanomolar naloxone attenuates neurotoxicity induced by oxidative stress and survival motor neuron protein deficiency. Neurotox Res 2014;25:262-70.

21. Fisher K, Coderre TJ, Hagen NA. Targeting the N-methyl-Daspartate receptor for chronic pain management. Preclinical animal studies, recent clinical experience and future research directions. J Pain Symptom Manage 2000;20:358-73.

22. Mei XP, Zhou Y, Wang W, et al. Ketamine depresses toll-like receptor 3 signaling in spinal microglia in a rat model of neuropathic pain. Neurosignals 2011;19:44-53.

23. Mion G, Marchetti F, Samama CM. Compassionate use of intrathecal ketamine for intractable cancer pain (Lett). Ann Fr Anesth Reanim 2013;32:621-2.

24. Dale O, Somogyi AA, Li Y, et al. Does intraoperative ketamine attenuate inflammatory reactivity following surgery? A systematic review and meta-analysis. Anesth Analg 2012;115:934-43.

25. Murrough JW. Ketamine as a novel antidepressant: From synapse to behavior. Clin Pharmacol Ther 2012;91:303-9.

26. Hudetz JA, Iqbal Z, Gandhi SD, et al. Ketamine attenuates post-operative cognitive dysfunction after cardiac surgery. Acta Anaesthesiol Scand 2009;53:864-72.

27. Feltracco P, Barbieri S, Rizzi S, et al. Brief report: perioperative analgesic efficacy and plasma concentrations of $S(+)$-ketamine in continuous epidural infusion during thoracic surgery. Anesth Analg 2013;116:1371-5.

28. Rojas AC, Alves JG, Moreira E Lima R, et al. The effects of subarachnoid administration of preservative-free $S(+)$-ketamine on spinal cord and meninges in dogs. Anesth Analg 2012;114:450-5.

29. Karpinski N, Dunn J, Hansen L, et al. Subpial vacuolar myelopathy after intrathecal ketamine: Report of a case. Pain 1997;73:103-5.

30. Stotz M, Oehen HP, Gerber H. Histological findings after long-term infusion of intrathecal ketamine for chronic pain: A case report. J Pain Symptom Manage 1999;18:223-8.

31. Malinovsky JM, Lepage JY, Cozian A, et al. Is ketamine or its preservative responsible for neurotoxicity in the rabbit? Anesthesiology 1993; 78:109-15.

32. De Kock M, Loix S, Lavand'homme P. Ketamine and peripheral inflammation. CNS. Neurosci Ther 2013;19:403-10.

33. Yan J, Jiang H. Dual effects of ketamine: Neurotoxicity versus neuroprotection in anesthesia for the developing brain. J Neurosurg Anesthesiol 2014;26:155-60.

34. Sylvester RK, Lindsay SM, Schauer C. The conversion challenge: From intrathecal to oral morphine. Am J Hosp Palliat Care 2004;21:143-7.

35. Krames ES. Intraspinal opioid therapy for chronic nonmalignant pain: Current practice and clinical guidelines. J Pain Symptom Manage 1996;11:333-52.

36. Deer TR, Prager J, Levy R, et al. Polyanalgesic Consensus Conference 2012: Recommendations for the management of pain by intrathecal (intraspinal) drug delivery: Report of an interdisciplinary expert panel. Neuromodulation 2012;15:436-66. 


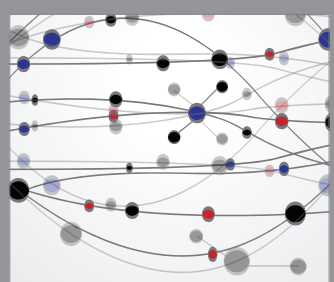

The Scientific World Journal
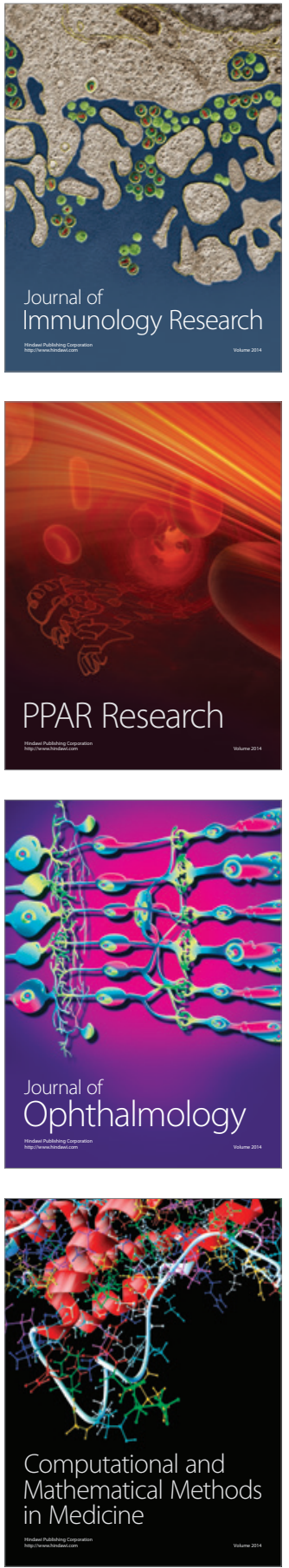

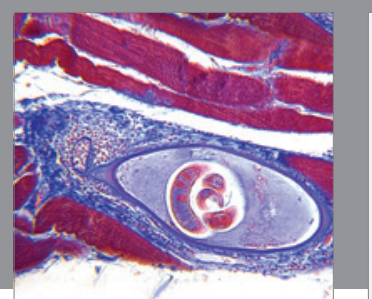

Gastroenterology Research and Practice

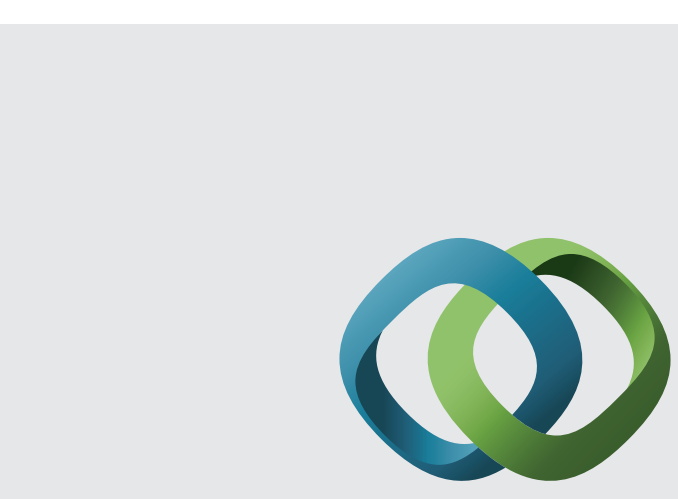

\section{Hindawi}

Submit your manuscripts at

http://www.hindawi.com
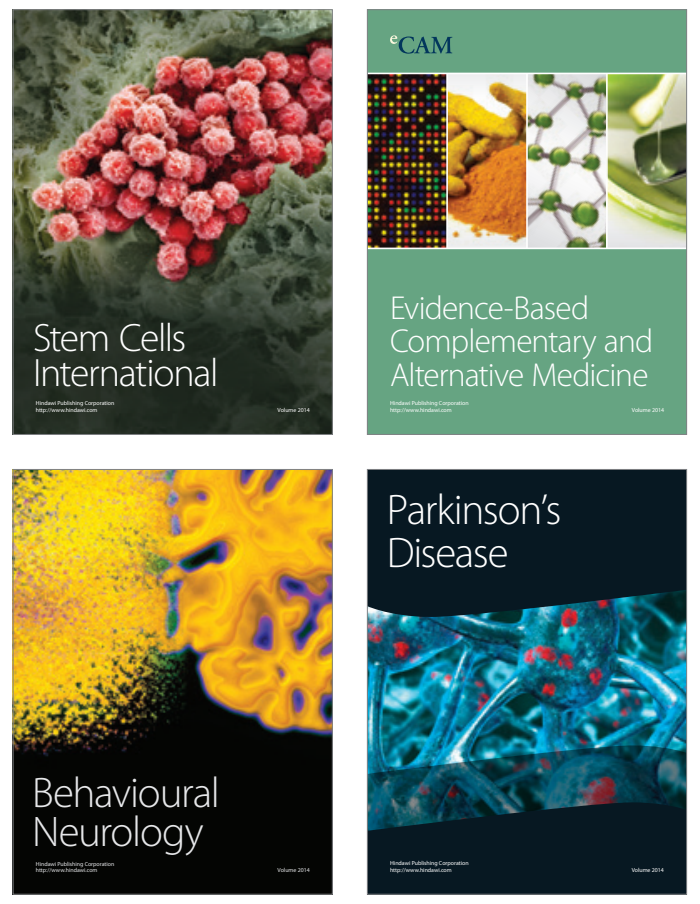
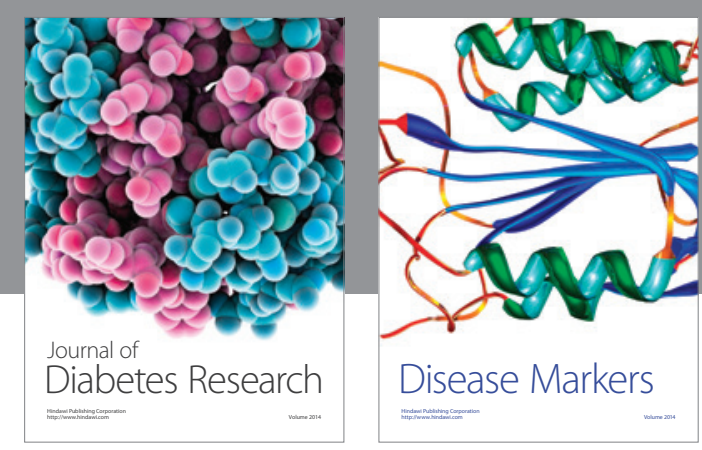

Disease Markers
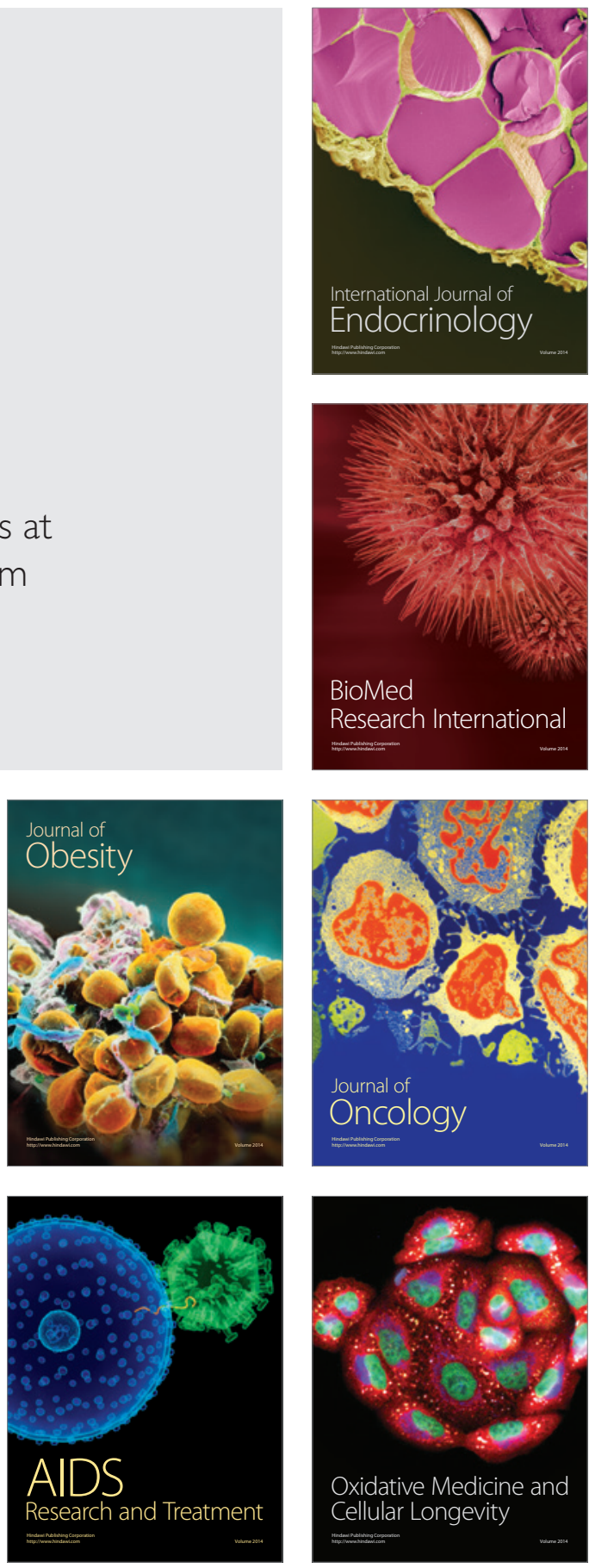